計でをる。

（3）性 能選別可能の蝺围は, 抵抗值は $10 \Omega$ $\sim 10 \mathrm{M} \Omega$, 静電容量は $0.0001 \mu \mathrm{F} \sim 1 \mu \mathrm{F}$ ，インダクタ ンスは $1 \mathrm{mH} \sim 100 \mathrm{H}$ である. 試験の結果, 選別速度は 前述のような 5 種選別の場合で每秒 1 個, まを選別精 度和よび安定度はんずれも実用上十分であつた。

\section{4.むすび}

以上電気回路部品の各種選別装置につルて, 主とし てその原理を説明した．紙面の都合上それらの特性な ぞについては十分に述べるととができなかつたが，そ の詳細は参考交献によつて承知されたい。

これらの選別装置は一応電気的な量につ々ての選別 を行ら目的で作られたものではあるが，とれはまた一
般的な物理量の選別にも利用できる。それにはその物 理量を選別々適した電気的の量に変換する装置を設け さえすればより，今後との装置は多くの分野の工業製 品の選別反広く利用されるであらうととが期待される。 注: -

1) Electronics, Vol. 21, No. 1 (1948)

2) 仲丸・大井, 第25回電気連合大会予稆, No. 8.22 (昭26-5)

3）酒井，第26回電気連合大会予稿，No. 15.8 (昭27-5)

4) F. Laude, Regelungstechnik, Vol. 1, No. 5 (1953)

5) A.W. Daubendick, Electronics, Voi. 21, No. 2 (1948)

6) D.A. Griffin \& N.B. Smalley, Electronics, Vol. 16, No. 2 (1943)

7) R.D. Campbell \& E.J. Totah, Electronics, Vol. 21, No.1 (1948)

8）昭和27年以降の電気連合大会で数回にわたつて報告してあるが, 詳細は目下電気学会雑誌に寄稿中

\title{
新しい繊度測定器 “バイブロスコープ”*
}

小野木重 治**

\section{1. 緒}

軽らものの形容に「吹けげ飛ぶような」といら言葉 がよく使われる. 真綿の小さいかけらが火鉢の上で上 梨気流飞流され，子供の吹く息で天井までも昇光光 を誰しもよく見かける。疼かの䋊維の場合でも大同小 異である。纃維とそは上の形容にびつたり当てはまる ものと言わねばねらない。

繊維の細さの程度, すなわち緎度を表わす単位の一 つイデニール(denier) というのがある１デ゙ニールの 緎維と口えば, 公定水分を含有した状態で $9000 \mathrm{~m} の$ 重さが $1 \mathrm{~g}$ の纎維のととである.したがつて, との纎維 $1 \mathrm{~cm}$ の質量はわずか火 $1 / 9 \times 10^{-5} \mathrm{~g}$ すねわち約 $1 \mu \mathrm{g} て ゙$, 普通の化学天科の感度のね和 $1 / 100$ 亿過さねん.デニ ールの測定には重量法が慣用されているが, 正確なデ ニール数を求めようとすれば, 高感度の天科を使うと しても相当量の試料を必要とする。その結果, もし試 料として纎維束あるいは系を使用するとすれば, 個々 の繊維の緎度の間にかなりの差異があるにもかかわら す平均化されてしまう。まをもし試料として 1 本の長 ら単繊維を使用するとすれば, 長さの方向に相当の緎 度斑のあるのが普通であるが，各部分の織度を知ると とはでをない. 重量法で求められるデニールは比較的 多量の試料全体についての平均值に過きない。またス フのように短かく切断された繊維の個々のデニール数

* 原稿受付 昭和 29 年 6 月 1 日

** 正員 京都大学工学部䋞維化学教室
は普通の方法ではとうてい測定できないのであるが、 しばしばそれの必要な場合が起る。特に単繊維の機械 的性質，たとえば切断強度の試験和レてそらであ る。とのような試験では短かい試料を使用し, 普通切 断強力の実測値をデニール数で割つて, 結果を $\mathrm{g} /$ デ ニールの単位で表わす.との場合デニールとして重量 法で得られる平均值を使用する以外飞方法がないの で, 試料が太かららが細かららが, 同し数で強力を割 らねばならない。換言すれば各試料の真の強度は求的 られないのである。この不合理をしいて排除しようと 思えば，絾維が膨潤とか収縮などの寸法変化を起さな ロような条件の下で,一々横断面の顕微鏡写真を撮つ て，その面積を測定せねばならない。その労はまこと 飞大をく，また寸法変化が全く起らなかつたとの確証 を得るととも困難である.もつとも横断面が形であ る時は直径を測定すればよりので，此較的容易ではあ る.

上に一寸触れを瀻度斑は系の品質に直接関連した非 常に重要な問題である。もし，乙の繊度斑を簡単かつ 正確㮯みうるならば, 生産管理の面で資する点が大 きいのであるが, 在来の方法に頼つている限り, これ はとうてい不可能といわねばならない.

かように考えてくると, 短かい繊維の緎度を迅速か つ正確に測定する方法の意義が明らかにぬつたととと 思うが, 実際とのような方法恰久しく繊維研究者, 技 術者の待望の的であつた。

天秤によらないで微量の質量を测定する方法, しか 
も誰もがなる存どと合点するようねコロンブスの卵的 方法が忽然として出覞した。 1947 年オランダの Gonsalvesの報文K見られる“Vibroscope”がそれである。 この方法は緎維を絃として振動させ，近仙的にはその 長さ, 張力, 和よび振動数から, 厳密には弾性に対す る補正を加兊てその単位長さ当りの質量, したがつて デニールあるいは断面積などを決定する方法である。

Gonsalves の研究化引続き,アメリカの Dart 扣 よび Peterson, Montgomery 护よび Milloway, Lindberg, イギリスでは Sproule が相次いで研究結 果を発表している. 著者むとの方法を採用して各種緎 維のデニールを測定した．Dart などの装置は和そら く既に製品化され市販されているのではなかららか。 わが国でもバイブロスコープに対する関心はようやく 高まり, 繊維関係の工場, 研究所で研究を開始し, ま そ計画中の処が增加しつつある. 高性能かつ簡便なバ イブロスコープの製品化が望まれている今日，その発 展のあとををどり，その原理，構造，非よび応用例飞 ついて解説するととは無益でねいと考元, 綜説を試み た次第である。

\section{2. 原理}

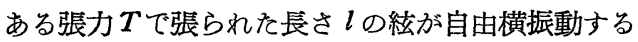
時の振動数は，振動の様式によつて異なる。絃全体が つつとなつて振動する時の振動数が最す低く, 次式で 与えられる。

$$
\nu_{1}=\frac{1}{2 l} \sqrt{\frac{T}{\rho A}},
$$

そどし $\rho$ は密度, $A$ は断面積で, 両者の積 $\rho A$ は単位 長の質量に相当し, 線密度と呼ばれる。乙の最も振動 数の低音を基(原)音といら．絃が二つ三つに分れて 節のある振動を行う時, するわち倍音では，振動数が

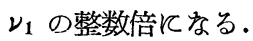

$$
\nu_{n}=n \nu_{1}(n=2,3,4, \cdots \cdots) .
$$

これらは絃が完全に曲りやすい場合であつて, 実際に は瀻維が曲げと対する抵抗すねわち曲げかたさを有す るため, それ対する補正が必要となる。すなわ

$$
\nu_{n}=n \nu_{1}\left[1+\alpha+\left(1+1 \cdot 234 n^{2}\right) \alpha^{2}+O\left(\alpha^{3}\right)\right],
$$

ただし $\alpha$ は

$$
\alpha=\sqrt{4 E I / l^{2} T},
$$

で，Eは緎維のヤング率，Iは断面の慣性能率，積 $E I$ は曲げかたさである：をとえば直径 Dの円形断面に対 しては $I=\pi D^{1 / 64}$ となる. らま $I=r A^{2}$ と表わすと とにする. 形断面では $r=\pi / 4$ である.

バイブロスコープでは絃を目由振動させるのではな く，固定端の一方に外部から振動を与えるととによつ て絃を強制振動させる. この時外から与える振動数と

* かれらの最初の報文(1949年)では“Vibrascope”と呼ばれていた が, 1952年の報文では Vibroscope に改められている。
絃の固有振動数とが一致する時最大の振巾を示す．す なわち、、わゆる共振現象が起る。したがつて常に共 振点を観測するとすれば，共振々動数に対して上の関 保式はそのまま使用できる。

式( 3 )和よび ( 4 )の関係を $\rho A$ 上の項は無視して）解けば次式を得る。

$$
\rho A=\frac{T}{4 l^{2} \nu_{1}^{2}}\left[1+2 \alpha+\left(3+2 \cdot 47 n^{2}\right) \alpha^{2}\right] .
$$

右辺の $\alpha$ の中には $I$, したがつて $A$ が含まれている ことを考慮してとの式を書き換えると次のようにな る.

$$
\rho A=\frac{T}{4 l^{2} \nu_{1}^{2}}\left[1+\frac{\sqrt{r E} \sqrt{T}}{\rho l^{3} \nu_{1}^{2}}+\frac{7+2 \cdot 47 n^{2}}{4} \frac{r E T}{\rho^{2} l^{6} \nu_{1}^{4}}\right] .
$$

(3) ( 5 ) 式の $\alpha$ の值は, 曲げかをさ $E I$ が小さいね ぞ,また張力 $T$ および長さ $l$ が大きいほど小さくな

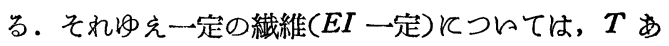
るいは $l$ を大きくすればいくらでも小さくなり，終り には 1 亿くらべて安全て無視でをるようになる。ての 時

$$
\rho A=T / 4 l^{2} \nu_{1}^{2},
$$

である.したがつて諸量をすべて C.G.S. 単位で表わ すとすれば, $\rho A$ は $1 \mathrm{~cm}$ 当りの質量をグラムで表わし

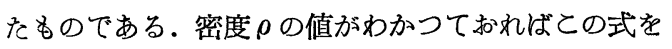
使つて断面積 $A\left(\mathrm{~cm}^{2}\right)$ を計算するとともでをる。 また デニールは定義により $9000 \mathrm{~m}$ の質量であるから， $\rho A$ の $9 \times 10^{5}$ 倍となり

$$
\text { デ=-ル }=\rho A \times 9 \times 10^{5}=9 T \times 10^{5} / 4 l^{2} \nu_{1^{2}},
$$

で与えられる。

このように $l$ 和よびTを大をくすれば, 補正が不必 要となり非常に簡単になるのであるが，これには和の おから限度がある。試料長はをとえばスフなどの切断 緘維ではせらぜい数cm以上にはできないしまを張力 を大きくすれば測定中に繊維の受ける変形が大をく， 正しら結果の得られは的それが多分にある。それで $l, T$ を適度の大きされとどめ, その代りに補正を施す のが賢明である、レまとの補正がどの程度のものであ るか考劣て見よう.1〜2.5デニールのレーヨン䋐維 で, $l=2 \mathrm{~cm}, T=20 \mathrm{mg}$ (18ダイン)とする時 $\alpha$ の值は 約 $0 \cdot 01$ となる. $2 \cdot 5 \sim 5$ デニールの繊維で, $l=4 \mathrm{~cm}$,

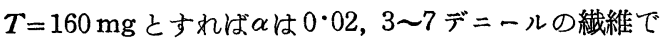
$l=4 \mathrm{~cm}, T=240 \mathrm{mg}$ の時 $\alpha=0.02 \sim 0 . C 3$ となる. した がつてデニールに対する補正に直せば, 上の数字の倍 になつて 1〜6\% とデニールとともに増大し, 決して 無視できない大きさになる。

第1 表には Montgomery らの報交に記載されてい る各種繊維に対する補正項 $\alpha$ の計算值を示した。

次にとのよらな補正は実際上的化して行かれるか であるが, Gonsalves, Dart,版よ゙ Peterson はいす。 
第1表 種々の繊維に対するかたさの補正

$l=2 \cdot 50 \mathrm{~cm} ; T=150$ dynes ; $A=\pi D^{2} / 4$ )

\begin{tabular}{|c|c|c|c|c|c|}
\hline 物' 筫 & $\begin{array}{c}\rho \\
\left(\mathrm{g} / \mathrm{cm}^{3}\right)\end{array}$ & $\begin{array}{c}D \\
(1 /) \\
\end{array}$ & $\begin{array}{c}A \\
\left(\mu^{2}\right)\end{array}$ & $\begin{array}{c}E \\
\text { (dynes/ }\end{array}$ & $\left(\mathrm{cm}^{2}\right)$ \\
\hline 羊 & $1 \cdot 31$ & $22 \cdot 0$ & 380 & $4 \times 10^{10}$ & ${ }^{10} 1.38 \times 10^{-8}$ \\
\hline 木 線 & $1 \cdot 53$ & $(16 \cdot 8)$ & 220 & 5 & 0.89 \\
\hline ビスコースレーーョン & $1 \cdot 54$ & $16 \cdot 7$ & 220 & 10 & $1 \cdot 26$ \\
\hline ナイロン ( V) & $1 \cdot 15$ & $19 \cdot 3$ & 290 & 8 & $1 \cdot 48$ \\
\hline$(0.001$ in. $)$ & 77 & $25 \cdot 4$ & 510 & 190 & $12 \cdot 7$ \\
\hline
\end{tabular}

第 2 表 レーヨン繊維のデニールの比較

\begin{tabular}{|c|c|c|c|c|}
\hline \multirow{2}{*}{\multicolumn{2}{|c|}{ 試 }} & \multirow{2}{*}{ 料 } & デ = & $r$ \\
\hline & & & バイブロスコープ & 顕 微鏡写真 \\
\hline \multirow{2}{*}{ 糸 1\{} & \multicolumn{2}{|c|}{$\int$ 太心単㵶維の平均 } & $4 \cdot 21$ & $4 \cdot 22$ \\
\hline & 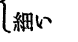 & I & $2 \cdot 24$ & $2 \cdot 23$ \\
\hline \multirow{2}{*}{ 糸 2} & $\int 太 W$ & ע & $4 \cdot 91$ & $5 \cdot 07$ \\
\hline & 細い & $\geqslant$ & $3 \cdot 75$ & $3 \cdot 73$ \\
\hline
\end{tabular}

れも実験的《行つている。それ《は幾つかの方法が考 客られるが, 直接には高感度のトージョンバランスな ぞを使用して，繊維束あるいは系のデニールををず重 量法で決定し, 単繊維当りのデニール飞換算する. 次 レでその束あるいは系に含まれる単緎維を取り出し て，それらのデニールをバイブロスコープで測定し， その平均值と先に求めを值とを比較するととによつて 補正を施している。まを顕微鏡的飞観測される值と比 較するととによつて，バイブロスコープの精度を查照 するとともできる。たとえば第2表は Dart らの結 果で, 大をい孔と小さい孔をもつをジェット（紡絲口 金）使つて紡糸した 2 種の糸について，バイブロス コープと顕微鏡で測定した単繊維デニールの比較であ る. これらの測定は各々 40本の試料について行われた ものであるが，2つの方法で得られた值はかぬりよく 一致している。乙れと同様の結果についてはさらに応 用例の項に扸にて述べよう。

以上はすべて繊維が長さの方向に全く均一であると して取り扱つてをたのであるが，実際には繊維断面の 不均一性の影響を考慮しなければならない。最近 Montgomery はこの問題に対して理論的考察を加え ているが, 複雑になるのでここでは触れないことにし た.

\section{3. 構 造}

上述の通り，線密度あるいはデニールを決定する量 は補正項は別反考元るとして, 試料長 $l$, 強力 $T$, 和よ ど共振々動数レの 3 者である. したがつて，てのうち 站れか 2 つを固定し，他の 1 つを変化させるととに よつて共振状態にもをらすととができる。それゆえバ イブロスコープは本質的に異なる次の 3 つの型に分類
できそその分類に応じ装罢の構造も変わる。

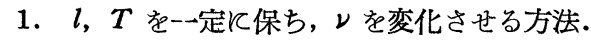

2. $l, \nu$ を一定保ち， $T$ を変化させる方法.

3. $\nu, T$ を一定保ち， $l$ を変化させる方泆. この最後の方法は当然可能であるともかかわらず, 全 くといつてよいねど採用されていない，わずか火河合 氏らの使用例があるに過を゙ない。したがつて以下 1 利 よび2の方法について順次紹介するととにしよう。

Gonsalves の装置ではラウドスピーカーの振動部に クランプを取り付け，てれに繊維の上端を摤む。䋐維 の下端とアルミニウムの荷重を接着テープの小片で貼 りつけ，一定張力を与光る。これらの中間によく研磨 した鋼製のピンを置き，試料緎維をその先で支える。 クランプの下端からとのピンまでの長さは一定の值に 保つ. 周波数範囲 500 1 $200 \mathrm{cps}$ の可聴周波発振器 の出力をスピーカーに与立て振動させ，周波数を変え て行くとある周波数で振巾は最大になる。その観察に は倍率約50倍の拡大鏡を使用し, 発振器のダイアルル 直接デニールを目盛つて計算の手数を省略している.

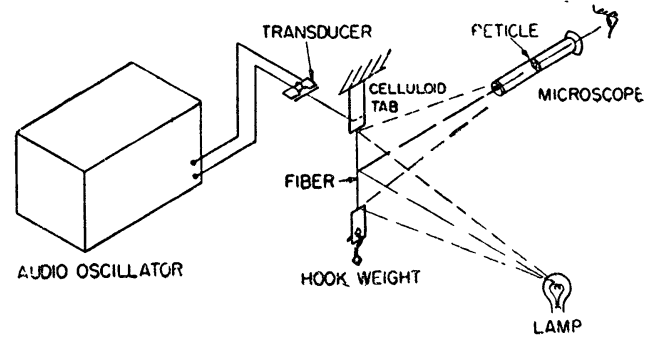

Fig. 1. Schematic diagram of electromechanical vibroscope. (After D. J. Montgomery and W. T. Milloway)

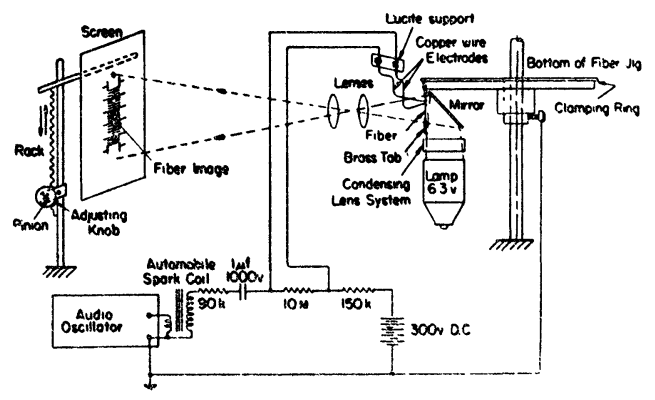

Fig. 2. Schematic diagram of electrostatic vibroscope. (After D.J. Montgomery) and W.T. Milloway)

Figs. 1 および 2 と示したのは Montgomery などの 報文に揭載されている 2 種の装置の模式図である. 最 初の装置はバィブレータとして電磁変換器 (electromagnetic transducer) を使用している点では上堎 置と同じであるが, 試料を直接バイブレータに取り付 けないで，セルロイド板を介して間接的に振動させて 
レる点放よびピンを使用しなら点が異なる．Fig. 2 の 装置は紪維を振動させるのに静電力を用いている点が 最大の特徴で，他に例を見な的ものである．可聴周波 発振器からの出力電圧をスパークコイルによつて 500 〜2000V 亿高めた上，試料接近して和かれれを銅線電 極に与える. 別に 200〜300 ボルトの直流バイアス電

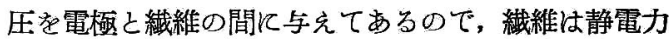
によつて振動する。委そこの装置では観察を容易にす るため,ス・リリーン上に絨維全体の像を拡大映写する 考案がなされている. バイブレータに電磁変換器を使 う電磁法は，費用低廉で簡便であると的う長所を有す る反面，繊維の位置に注意を要し，バイブレータ自身 の共振に細心の注意を払わねばならないなとの短所が ある.静電力に上万励起の方法は費用す低廉で, 䋊維 との機械的接触のない点は大きい利点になるが，電父 回路の複雑さ，過剩電圧による瀻維損傷の伦険性，高 抵抗㰇維に対する測定の团難さなどの久点を免れえな r.

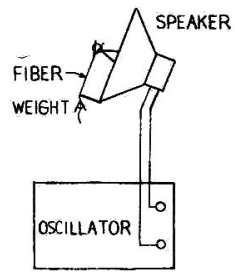

(A)

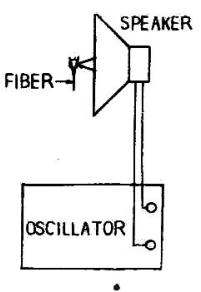

(B)
Fig. 3. Schematic diagram of the author's apparatus.

(A) for determination of denier, and (B) for determination of flexural rigidity.

著者の用らそ装置は模式的に示すと Fig. 3 の通り

で，20〜20000 cps の可聴周波発振器およひパーマネ ントダイナミックスピーカを使用した.この装置は単 繊維デニールの測定とともに，曲げかたさあるいはヤ ング率をも測定できるようにしたものである。デニー ルの測定に際しては, 瀻維の下端を一定重量のクリッ プで㙖んで張力を与え，絃として振動させる。曲げが そさを測定する時には繊維老短く(長さ数 $\mathrm{mm}$ ) 切つて 下端は自由にし，片持梁として振動させる。乙の時の 共振及動数 $\nu_{r}$, 試料長 $l$ から曲げかたさ $E I$ は次式学 使つて求められる。

$E I=3 \cdot 549 \times$ denier $\times \nu_{r}^{2} l^{4} \times 10^{-6}$.

次に繊維長, 振動数を一定に保ち, 張力を変化させ る方法につ的て述べる。これの典型的なのが Dart 拈 よび Petersonの装置である。かれらが最初に報告し た装置の模式図在 Fig. 4 K示す。振動数は $1000 \mathrm{cps}$ に, 蟣維長は $1 \mathrm{in.}$ 附近の一定値に固定し, 繊維の下 端にクランプを通して鎖荷重を附ける.鎖の他端を上
下するととによつて荷重, したがつて張力の大をさを 連続的飞任意飞変化させる ととがでをる.Fig. 5 亿示 したの站良型バイブロス コープの写真であるが，こ の装置では鎖の端をがイア ルに取り付け，その目盛に よつてデニール数が直続で きるよう改良されている。 ふ打最初の装置ではスピー カーがそのまま使用されて

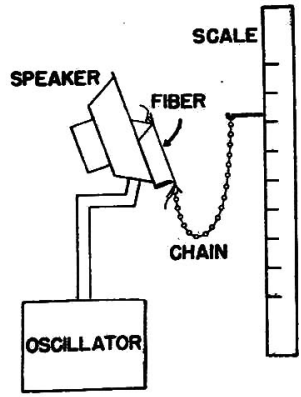

Fig. 4. Schematic diagram of the vibrascope. (After S.L. Dart and L.E. Peterson)

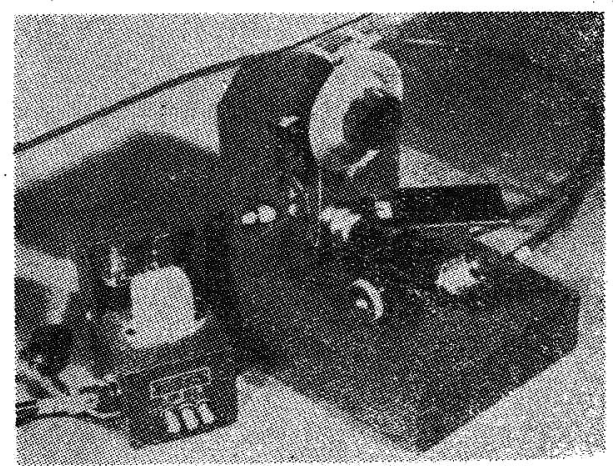

Fig. 5. Photograph of the improved vibroscope. (After S.L. Dart and L.E. Peterson)

いたが,との 改良型ではピ ッアップク リスタルにク ランプを取り 付けをバイブ レータが使用
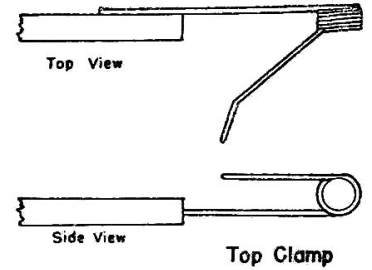

されている。

Fig. 6 は上下 のクランプ 学 図示したもの である..クラ ンプは非常に 軽く, 乙か。 繊維在確実に 把握する必要 がありその
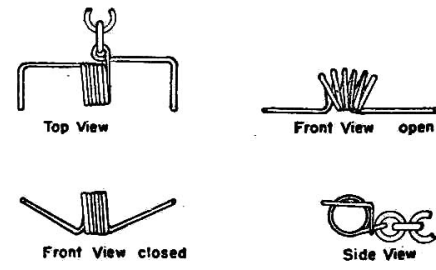

Bottom Clamp

Fig. 6. Fiber clamp assembly. (After S. L. Dart and L.E. Peterson)

整作には苦心党伴うが，乙の図に示されたような不銹 䤱製のスプリング式のもの (5 mg 程度のすのまで作れ

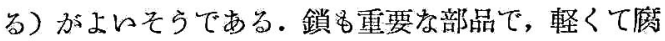
蝕されなら，しかも線密度の均一なものが必要であ る. Dart らは金または白金製の線密度 $50 \mathrm{mg} / \mathrm{cm}$ の 
鎖を使用している.

Lindberg が羊毛紻維の研究に当つて使用した装置 もとの分類属するものであるが，振動の与方方和よ び共振時の㖘力をインストロン試験機のグラフ上に記 録した点が異なり，また瀻維断面の測定と同時に荷重 伸長率曲線の得られる特徴を有している.

Sproule は温湿度変化による系の重量変化を測定す る目的で，同一原理に基づく装置を製作し，使用した。 らままで述べを装置と異なる点は, バイブレータとし てマグネトストリクションバイブレータを使用し,さ ら反共振点をより正確に探知する目的で検波結晶とブ ラウン管オッシロスコープの系を使用している点, 系 につレて測定を行うので非常に長ら試料(全長 $1 \mathrm{~m}$ あ まり)を使用している点などである。

以上で今日までに製作使用されてをたバイブロスコ 一プの構造につけての簡単な紹介を終るが, 次には実 際バイブロスコープを実用化するとして1の方法を選 ぶべきか，2の方法を選ぶべをかが問題になる。しれ は一概に論しられない間題で, な和今後の検討て待た ねばならない多くの点があるが, デニール測定専用の 装置を製作するのであれば，むしろ 2 の方法を選択す る方が有利ではなかららか。、いま少し詳細仙两方法の 相違点, 得失を考察しよう。

まず補正項についてであるが，(8)式から明らかぬよ ら飞, 主要補正項は 1 の方法によれば $1 / \nu_{n}^{2}$ するわち $\rho A$ のほ济一次で変化するが，2の方法によれば $\sqrt{T}$ すなわち $\sqrt{\rho A}$ として変化する. その結果 2 の方法で は紻維の太さによる補正項の変化が少なくてすむ（補

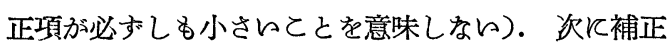
項は別として, デニールと張力とは直線関係にあるか ら，装置にデニールを直読でをる目盛变附ける場合に も張力を変化させる方が容易である. Dart なども自 分達の装置の最大利点として直読式であるため繊維を 取り扱ら時間,手数を最小にでを,測定を迅速容易に行 レらるのみならす，䋐維に損傷の機会を与皇ない点を 挙げている.さらに周波数を一定にする方法では，太
ら繊維は自然と大きい荷重を, 細繊維は小さい荷重 を受け,デニール当りには同じ荷重 (約 $0.03 \mathrm{~g} / \mathrm{denier}$ ) を受けるので, 相対的に同等に取り扱える点, および 発振器が簡単かつ低廉になる点が長所になる。

\section{4. 応用例}

すで飞前項に和いて，バイブロスコープ法と他の方 法で測定されたデニールの比較について述べをが，第 3 表には Montgomery らが羊毛繊維について質量測 定の比較を行つを結果を再録した。両者の值はかなり よく一致している．第 4 表には同じく 3 デニールナイ ロン纎維の直径をバイブロスコープ和よび顕微鏡で測 定した結果の比較である．との場合前者による值は断

第 3 表 羊毛䋐維の質量の比較

\begin{tabular}{|c|c|c|c|c|}
\hline \multirow{2}{*}{ 緎維番号 } & 全 凟 & 量 ( $\quad \mu \mathrm{g})$ & \multicolumn{2}{|c|}{ 差 } \\
\hline & バイプロスコープ & ミクロバランス & $\mu \mathrm{g}$ & $\%$ \\
\hline 1 & 567 & 574 & +7 & $+1 \cdot 2$ \\
\hline 2 & 587 & 600 & +13 & $+2 \cdot 2$ \\
\hline 3 & 521 & 507 & -14 & $-2 \cdot 8$ \\
\hline 4 & 578 & 574 & -4 & -0.7 \\
\hline 5 & 588 & 584 & -4 & -0.7 \\
\hline
\end{tabular}

第 4 表 ナイロン繊維の直径の比較

\begin{tabular}{|c|c|c|c|c|}
\hline \multirow{2}{*}{ 織維番号 } & \multicolumn{2}{|c|}{ 径 $(\mu)$} & \multicolumn{2}{|c|}{ 差 } \\
\hline & バイブロスコープ & 顯 媺 鏡 & $\mu$ & $\%$ \\
\hline 1 & $21 \cdot 2$ & $21 \cdot 5$ & -0.3 & $-1 \cdot 5$ \\
\hline 2 & $17 \cdot 2$ & $17 \cdot 1$ & +0.1 & +0.5 \\
\hline 3 & $25 \cdot 3$ & $25^{\circ} 4$ & -0.1 & -0.6 \\
\hline 4 & 18.5 & $18 \cdot 2$ & +0.3 & $+1 \cdot 6$ \\
\hline
\end{tabular}

第 5 表 レーヨン糸の単䋊維繊度斑

\begin{tabular}{l|c|c|c|c|c}
\hline 試 料 & 最大 & 最 小 & 平均 & \multicolumn{2}{|c}{ 平均偏 差 } \\
\hline 不均一系 & 5.55 & 1.71 & 3.77 & 0.79 & 0.05 \\
均一維間 & 維維方向 \\
\hline
\end{tabular}

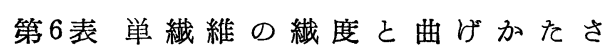

\begin{tabular}{|c|c|c|c|c|c|c|c|c|c|}
\hline & \multirow{2}{*}{ 試 } & & $=$ & - & $ル$ & \multirow{2}{*}{$\begin{array}{c}E I \\
\text { dynes } \cdot \mathrm{cm}^{2}\end{array}$} & \multirow{2}{*}{$E I /$ den $^{2}$} & \multirow{2}{*}{$\begin{array}{c}I \\
\mathrm{~cm}^{4}\end{array}$} & \multirow{2}{*}{$\begin{array}{c}E \\
\text { dynes } \cdot \mathrm{cm}^{-2}\end{array}$} \\
\hline & & 普 & 通 & 振 & 動 法 & & & & \\
\hline \multirow{3}{*}{\multicolumn{2}{|c|}{ 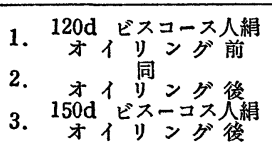 }} & \multicolumn{2}{|c|}{5.03} & & $4 \cdot 79$ & $0 \cdot 107$ & $4 \cdot 65 \times 10^{-3}$ & $0.976 \times 10^{12}$ & $1 \cdot 10 \times 10^{-11}$ \\
\hline & & \multicolumn{2}{|c|}{4.94} & & $4 \cdot 85$ & 0.119 & $5 \cdot 05$ & $1 \cdot 00$ & $1 \cdot 19$ \\
\hline & & \multicolumn{2}{|c|}{$4 \cdot 79$} & & $4 \cdot 22$ & 0.0803 & $4 \cdot 51$ & $0 \cdot 757$ & $1 \cdot 06$ \\
\hline 4. & ビスコーススフ 1 & & & & $2 \cdot 34$ & 0.0284 & $5 \cdot 18$ & $0 \cdot 233$ & $1 \cdot 22$ \\
\hline 5. & 同 & & & & $2 \cdot 12$ & 0.0278 & $6 \cdot 18$ & $0 \cdot 191$ & $1 \cdot 45$ \\
\hline 6. & アセテート人組 & & & & $3 \cdot 94$ & 0.0329 & $2 \cdot 12$ & 0.875 & 0.376 \\
\hline 7. & $\gamma \quad \Sigma$ & & & & $3 \cdot 64$ & & & & \\
\hline
\end{tabular}


面が完全ね円形であるとして算出したものであるが， 洏者はよく一致している。

バイプロスコープ老デニール站の判定に使用した例

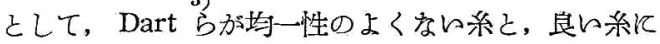
つ々て, 最大, 最小, 倣よび平均の単纎維デニールを 求め,さらに繊維相互間の平均俯差扣よび1本の繊維 の長さに沿つてのデニール偏差を測定した結果を第 5 表沶した。

Gonsalves は本綿, 羊毛, およどスフ繊維のデニー ルを測定した後直ちに切断强伸度試験に附した。その 結果は省略するが，乙のような試験によつて初めて 1 本 1 本の繊維の強度が正確佂求められるわけである.

著者らは主としてレーヨン纎維につ々て, 上述の装 置を使用して, ますデニールを決定した後, 各々の曲 げかをさ $E I$ 起测定した。結果を第6表に掲げる.こ の表の断面の慣性能率 $I$ 扣よびヤング率 $E$ の值は断面 が円形であるとして算出したものである。注意すべき はバイブロスコープで測定されたデニールの值（振動 法の闌）が, アミランの場合を除けば常に重量法で得 られて值(普通の闌)より相当低らととである.われわ れはとれを主として断面の四形からの偏倚に帰してい る.

\section{5. 結 び}

バイブロスュープの誕生以来すでに数年の歳月が流 れたが，その普及にはまだをとで見るべきものがな ら.それは手軽彷手して，簡単に測定でさる製品が 生れていならからである.しかし，ち数年も経てば, ビとの繊維研究所, 試験室にもバイブロスュープの姿 が見られるであろら。との一交がその普及に対して多 少とも役立つならば著者の悦びとするところである.

終りにのぞみ終始御指道を賜つている㻕尾教授に梁 甚な謝意を表明する。

注: 一

1) V.E. Gonsalves, Textile Research J., 17, 369 (1947)

2) S.L. Dart, L.E. Peterson, ibid., 19, 89 (1949)

3) S.L. Dart, L.E. Peterson, ibid., 22, 819 (1952)

4) D.J. Montgomery, W.T. Milloway, ibid., 22, 729 (1952)

5) D.J. Montgomery, J. Applied Phys., 24, 1092 (1953)

6) J. Lindberg, Textile Research J., 23, 67 (1953)

7) D.O. Sproule, J. Textile Inst., 43, T 455 (1952)

8) 小野木, 安藤, 㵶維学会誌, 9, 617 (1953)

9) A. Seebeck, Abhandl. math.-phys. Klasse sächs. Ges. Wiss. (Leipzig) (1852). あるいは,たとえば P.M. Morse, "Vibration and Sound" 2 nd ed., New York, McGrawHill, p. 170 (1948)

10）藤野, 河合, 堀野, 宮本, 関西工学速合講演会 (1952)

\section{ボールトウイン SR-4 較正装置}

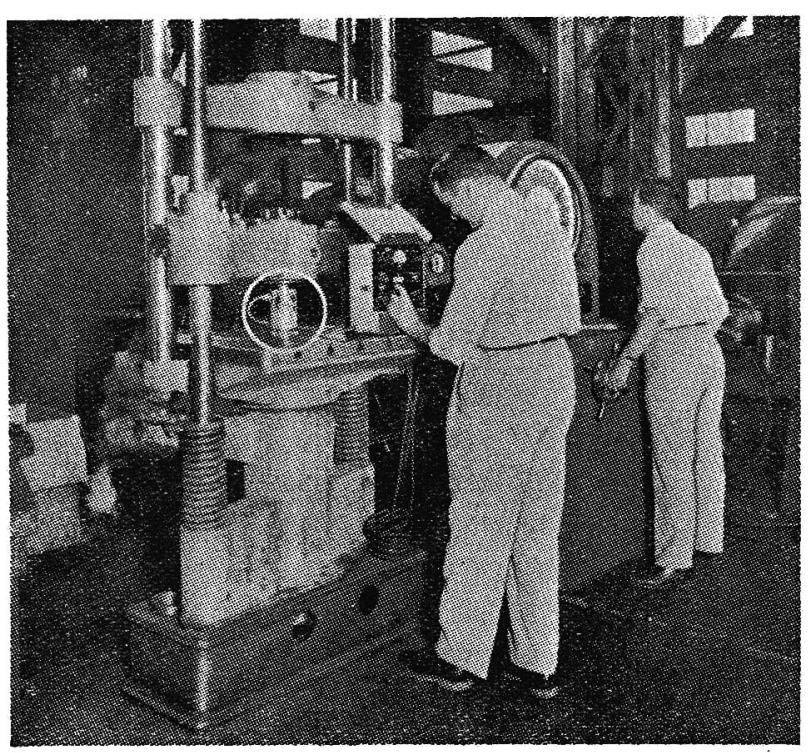

近著の Baldwin Lima-Hamilion Corporation の Bulletin 4303 によれば, 同 社は SR-4 Calibration Kit 発発売してい る. 乙れは, Load cell $(60,120,240$, $600,1200,2400,6000,12000,24000$, 60000,120000 ポンド—も張, 压縮用, $24000,60000,120000,240000$ ポンド - 一正縮用), Indicator, Standardizer, Instruction book よりなり, 写真はとの 使用状况を示す，写真の四内は load cell, その横は Indicator である.これは 写真よりすれば，普通の坐測定用の portable strain indicator と大差はないよう である。 